\title{
MOLE-RATS NANNOSPALAX LEUCODON AND SPALAX ZEMNI IN UKRAINE: IDENTIFICATION CRITERIA AND BORDER BETWEEN THEIR RANGES
}

\author{
I. Zagorodniuk, M. Korobchenko, V. Kirichenko \\ National Museum of Natural History, NAS of Ukraine (Kyiv) \\ Bohdan Khmelnytsky St. 15, Kyiv, 01030 Ukraine \\ State Sanitary and Epidemiological Service in Mykolaiv Oblast (Mykolaiv) \\ E-mail: zoozag@ukr.net
}

\begin{abstract}
Mole-rats Nannospalax leucodon and Spalax zemni in Ukraine: identification criteria and border between their ranges. - Zagorodniuk, I., Korobchenko, M., Kirichenko, V. — The differences between two mole-rat species are shown according to the complex of exterior and cranial characters, each of which is reliable in species diagnostics. In particular, they include the color of rhinarium, shape of the rostrum, development of lateral occipital apertures and pharyngeal tubules, also the flexion of the base of the skull, and expressiveness of the intercrestal fossa in the mandible. A number of collection materials were re-identified, which significantly changed the views on geographical ranges of these species. The boundary between species should be considered substantially shifted to the west: the Bug-Tylihul interriver area is inhabited not by $N$. leucodon, as it was believed so far, but by S. zemni. It is confirmed by both old specimens (1930-1950s) and modern materials (2010-2016), thus it is not associated with habitat changes. At the same time, monitoring of the dynamics of settlements of these species shows significant changes in the scope of inhabited areas, as well as recent colonization of the most part of the region from coastal refugia.
\end{abstract}

Key words: Nannospalax leucodon, Spalax zemni, cranial characters, distribution, ranges.

Сліпаки Nannospalax leucodon та Spalax zemni в Україні: критерії ідентифікації та межа між їх ареалами. - Загороднюк, І., Коробченко, М., Кириченко, В. - Показано відмінності двох видів сліпаків за комплексом екстер'єрних та краніальних ознак, кожна з яких є надійною в діагностиці видів, зокрема за кольором ринарію, формою рострума, розвитком бічних потиличних отворів, глоткових горбків та зламу основи черепа, виразністю на мандибулі міжгребеневої ямки. Перевизначено низку колекційних матеріалів, які суттєво змінили уявлення про ареали цих видів. Відома в літературі межа між видами суттєво зміщена на захід: у межиріччі Бугу та Тилігулу мешкає не N. leucodon, як вважали дотепер, a S. zemni. Це підтверджують як давні зразки (1930-1950-х рр.), так і сучасні матеріали (2010-2016 рр.), тобто це не пов'язано зі змінами ареалів. У той же час спостереження за динамікою поселень цих видів засвідчують суттєві зміни в обсягах заселених ними територій і недавнє заселення ними більшої частини регіону з приморських рефугіумів.

Ключові слова: Nannospalax leucodon, Spalax zemni, краніальні ознаки, поширення, ареали.

\section{Introduction}

Distribution of steppe terrestrial animals is very severely limited by the influence of a number of factors, among which hydrography has a leading role. The significance of river valleys in geographical distribution of steppe animals, including mammals, was repeatedly considered in the literature (e.g., Pidoplichko, 1936; Tsemsh, 1941; Zagorodniuk, 1999). Rivers are especially important in formation of geographical ranges of steppe underground mammals, in particular of mole-rats (Reshetnyk, 1941; Korobchenko, Zagorodniuk, 2009, 2016). In fact, distribution range borders of all species of Spalacidae are associated with large rivers, and the pair of species Nannospalax leucodon and Spalax zemni is not an exception (Topachevsky, 1969).

However, it is obvious that the fauna is in constant dynamics, and the boundaries of species ranges are constantly changing as well. In case of mole-rats it means the regular appearance of such factor of evolution and species distribution as interspecific competition, because mole-rats occupy 
similar ecological niches, regarding both trophic (feeding by bulbous plants and rhizomatous grasses) and spatial components (meadow and steppe habitats within a narrow underground ecotope). According to eco-morphological criteria, all mole-rats known in the European fauna are very close species, and their existence is possible only in the form of vicarious populations replacing each other in the space (Korobchenko, Zagorodniuk, 2009).

In this regard, the following two facts established during identification of new samples and reidentification of old collection specimens of mole-rats (Nannospalax leucodon and Spalax zemni) distributed in the Black Sea region appear important (and also unexpected before this research): 1) within the known by now range of Nannospalax leucodon there are records of another species, Spalax zemni, in particular in vicinities of Shyrokolanivka (Korobchenko, Zagorodniuk, 2009: based on samples obtained from K. Redinov) and in Berezivla district, Mykolaiv region (this article), as well as in Lyman (former Kominternove) district, Odesa region (ibid.); 2) denial of the previously prevalent and generally accepted idea that the distribution boundary between the two mentioned mole-rat species (and essentially two genera) is the Southern Bug river.

According to these facts and some other findings and sample re-identifications, it is obvious now that the boundary between the species runs to the west, most likely along the Tylihul river and the Tylihul estuary, however it requires further clarification. The purpose of this work is to describe the diagnostic characters and distribution features of two mole-rat species in the contact zone of their ranges and to compile the inventory of their records to specify the boundary between them ${ }^{1}$.

\section{Materials}

Collections of mole-rats deposited in the National Museum of Natural History of Ukraine (see: Korobchenko, 2014) were investigated, in both the Paleontological and Zoological departments (NMNHU-P and NMNHU-Z). Some morphological materials were studied using samples from the authors' working collection. Criteria for species diagnostics were described by the authors earlier (Korobchenko, Zagorodniuk, 2009; Korobchenko, 2012) and revised in this work in the light of identification of the pair of species Nannospalax leucodon and Spalax zemni.

\section{Criteria for species identification}

Key differences between the two species are compiled based on the authors' previous review (Korobchenko, Zagorodniuk, 2009) and some old publications (Yanholenko, 1966; Topachevsky, 1969). These characters are compiled and described in table 1 and illustrated on figs. 1-5. Metric characters were not analyzed. Characters were studied on samples deposited in NMNHU.

The main external identification criteria for this pair of species (and for Nannospalax and Spal$a x$ in general) that can be used in the field, as well as in identification by photo records, is the color of rhinarium, which is light-pink in N. leucodon and gray, dark gray, or black in all Spalax s. str., including $S$. zemni (fig. 1). This character was described first by Reshetnyk (1941), but it was lost in all identification keys, and re-described just a few years ago (Korobchenko, 2012 b).

Nannospalax leucodon and Spalax zemni have 5 distinct cranial differences, which, according to our research, play key role in diagnostics of these pair of species. Regarding the distal rostrum, an important feature is the form of the nasal part: in $N$. leucodon, the contour of the nasal part (top view) is rounded on the sides, whereas in $S$. zemni it has a trapezoidal shape with almost straight lateral edges (fig. 2). Clear differences between these species were also revealed in the structure of the occipital region: a characteristic feature is the presence of condylar canals above occipital condyles in N. leucodon, distinguishing it from the genus Spalax (fig. 3). In addition, an important character is the large development of pharyngeal tubercles and a flexion at the border of basioccipital and sphenoid bones in Nannospalax (fig. 4). On the mandible, an important character of Spalax is the development of lateral crest that runs from the alveolar to coronary process and limits the intercrestal fossa, which is typical for this genus (fig. 5).

\footnotetext{
${ }^{1}$ A detailed analysis of relationships between these species will be presented in a separate contribution (in press).
} 
Table 1. Key craniological differences between Nannospalax leucodon and Spalax zemni

Таблиця 1. Ключові краніальні відмінності між Nannospalax leucodon та Spalax zemni

\begin{tabular}{|c|c|c|}
\hline Character & Nannospalax leucodon & Spalax zemni \\
\hline Color of rhinarium & light-pink (fig. $1 l$ ) & light gray to dark gray (fig. $1 z$ ) \\
\hline $\begin{array}{l}\text { Form of the nasal part of the } \\
\text { skull (top view) }\end{array}$ & $\begin{array}{l}\text { The nasal part has an elliptical shape } \\
\text { with an expressive extension of its lateral } \\
\text { contours formed by the intermaxillar } \\
\text { bones (fig. } 2 l \text { ) }\end{array}$ & $\begin{array}{l}\text { The nasal part has almost straight lateral } \\
\text { outlines of the intermaxillar bones, which } \\
\text { converge only at the level of posterior } \\
\text { ends of nasal bones (fig. } 2 \mathrm{z} \text { ) }\end{array}$ \\
\hline $\begin{array}{l}\text { Condylar canals above oc- } \\
\text { cipital condyles (on both } \\
\text { sides of foramen magnum) }\end{array}$ & $\begin{array}{l}\text { On the sides of foramen magnum, there } \\
\text { are small lateral condylar canals above } \\
\text { the occipital condyles, occasionally they } \\
\text { can be absent (fig. } 3 l \text { ) }\end{array}$ & $\begin{array}{l}\text { On both sides of foramen magnum, there } \\
\text { are no lateral condylar canals above the } \\
\text { occipital condyles (fig. } 3 z \text { ) }\end{array}$ \\
\hline $\begin{array}{l}\text { Pharyngeal tubercles (lateral } \\
\text { edges of the basioccipital } \\
\text { bone between tympanic bul- } \\
\text { lae) }\end{array}$ & $\begin{array}{l}\text { The lateral edges of the basioccipital } \\
\text { bone (at the place of the respiratory tube) } \\
\text { do not form neither lateral ridges nor } \\
\text { smooth groove between them (fig. } 4 l \text { ) }\end{array}$ & $\begin{array}{l}\text { The lateral edges of the basioccipital } \\
\text { bone (at the place of the respiratory tube) } \\
\text { form distinct ridges with a smooth } \\
\text { groove between them (fig. } 4 \mathrm{z} \text { ) }\end{array}$ \\
\hline $\begin{array}{l}\text { Flexion at the basisphenoid } \\
\text { bone (between tympanic } \\
\text { bulla) }\end{array}$ & $\begin{array}{l}\text { There is a clear flexion at the suture } \\
\text { between the basisphenoid and basioccipi- } \\
\text { tal bones (fig. } 4 l \text { ) }\end{array}$ & $\begin{array}{l}\text { The suture between the sphenoid and } \\
\text { basioccipital bones is unnoticeable, with- } \\
\text { out a flexion in this place (fig. } 4 \mathrm{z} \text { ) }\end{array}$ \\
\hline $\begin{array}{l}\text { Intercrestal fossa on the } \\
\text { mandible (alveolar crest and } \\
\text { a pit limited by this crest) }\end{array}$ & $\begin{array}{l}\text { The alveolar crest on the mandible is } \\
\text { poorly developed and the concavity } \\
\text { between it and the inner crest does not } \\
\text { form an isolated pit (fig. } 5 l \text { ) }\end{array}$ & $\begin{array}{l}\text { There is a well-developed crest on the } \\
\text { lateral surface of the mandible, and a } \\
\text { deep pit between it and the internal (con- } \\
\text { dylar-coronal) crest (fig. } 5 z \text { ) }\end{array}$ \\
\hline
\end{tabular}
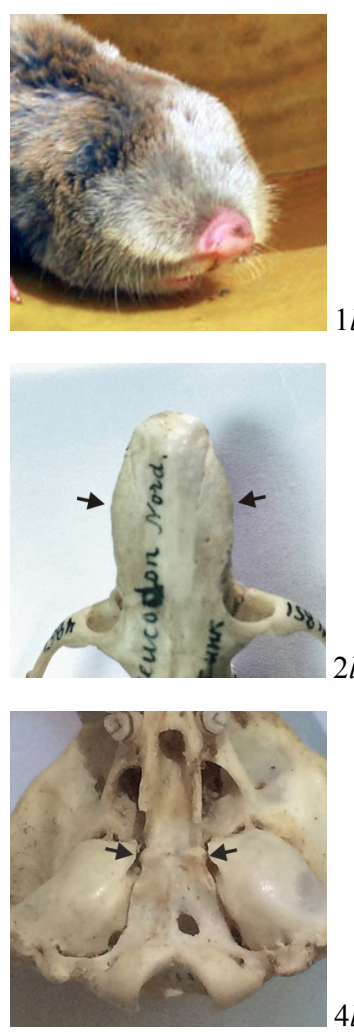

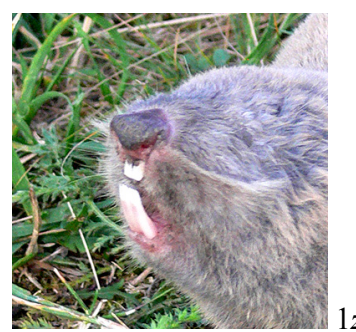

Fig. 1. Differences between Nannospalax leucodon ( and Spalax zemni $(z)$ by the color of rhinarium.

Рис. 1. Відмінності між Nannospalax leucodon $(l)$ та Spalax zemni (z) за кольором ринарію.
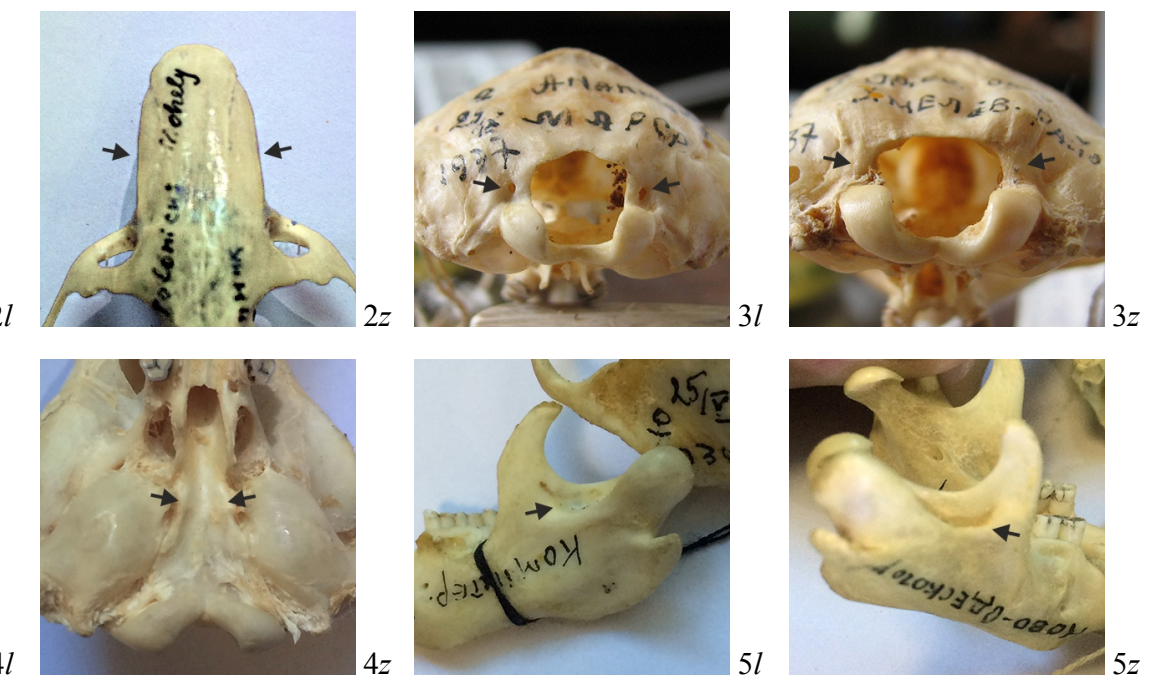

Fig. 2-5. Differences between Nannospalax leucodon $(l)$ and Spalax zemni $(z)$ : 2 - rostrum shape, 3 - lateral condylar canals, 4 - pharyngeal tubercles and flexion at the basisphenoid bone, 5 - intercrestal fossa.

Рис. 2-5. Відмінності між Nannospalax leucodon (l) та Spalax zеmni (z): 2 - форма роструму, 3 - бічні потиличні отвори, 4 - глоткові горбки та злам основи черепа, 5 - міжгребенева ямка. 


\section{Peculiarities of geographical distribution}

The main attention is paid to the records of mole-rats in the area between the east and north of Odesa region and the Dnister river. From the west, the area of records is limited by the OdesaPodolsk imaginary line; in biogeographic coordinates, this is the territory extending east of the Maly Kuialnyk river that flows southwest from Zakharivsky district (Birnosove vil.) to the Hadzhibei estuary near Odesa. This area drew attention after identification Spalax zemni in samples from Shyrokyi Lan (Korobchenko, Zagorodniuk, 2009), for which another species, Nannospalax leucodon, was indicated earlier (Rusev et al., 2014) ${ }^{2}$, just as for the right bank of the Dnister river in general (Reshetnyk, 1941; Topachevsky, 1969; Filipchuk, Yangolenko, 1986 etc.) ${ }^{3}$.

The complied cadaster includes only materials species identification for which has been carried out based mainly on cranial characters, studying collections, or (in some cases) specimen descriptions published in works of colleagues who specialize in the study of cranial characters of mole-rats (works by O. Myhulin, E. Reshetnyk, and V. Topachevsky). All localities are marked by the names of the nearest settlements, with indications of administrative districts.

\section{Records of Nannospalax leucodon}

The descriptions of 9 locations are divided into two groups: the first one includes localities in the north of Odesa region and the west of Mykolaiv region (4 localities), while the second group deals with the south of the Odesa region, i.e. strictly the Black Sea region (5 localities). In this score, there are also 17 locations in which mole-rats were recorded, but without species identification.

\section{A) Records in the north of Odesa region and the west of Mykolaiv region}

L1) Zherebkove (Ananyiv district, Odesa reg.). A specimen from Zherenkove mentioned in O. Myhulin's review as "Spalax leucodon, No. 867, Zherebkovo vil., Balta district" (Myhulin, 1938, p. 346), trapped 1.07.1928. In the collection of NMNHU-Z, there is a sample No. 9456 (skin, skull) listed in the catalogue as "Spalax microphtalmus, Odesa reg., Balta district, Zherebkove vil., 1.07.1928" (Shevchenko, Zolotukhina, 2005) $)^{4}$, i.e. the same specimen. However, this specimen was not found in the stocks of NMNHU, and the species identification was accepted here after O. Myhulin (loc. cit.).

L2) Selyvanivka (Ananyiv district, Odesa reg.). Two collected specimens are known. In the collection of NMNHU-Z, there is a specimen (skin and skull No. 5458) listed in the catalogue as "Nannospalax leucodon, Selevanivka vil., Ananyiv district, leg. E. Reshetnyk, 28.09.1937" (Shevchenko, Zolotukhina, 2005). We identified this skull with No. 5458 as leucodon. In the catalogue of NMNHU-P, this specimen is listed as "No. 3567, Spalax leucodon, skull, female, Selevanivka vil., Ananyiv district, 28.09.1937, Reshetnyk." The specimen was found in the collection of NMNHU-P: skull No. 3567 (without mandible): it is typical leucodon (as E. Reshetnyk indicated it on the skull).

L3) Pervomaisk (Mykolaiv reg.). A specimen from Pervomaisk was described by O. Myhulin (1938) as "leucodon" trapped in 1927 (7.06.1927) and deposited in the author's collection with No. 686. This specimen was found in the collection of NMNHU-Z: 1 spec. No. 9449 (skin, skull), as "Nannospalax leucodon, vicin. of Pervomaisk city, Mykolaiv reg., 7.06.1927, leg. ?” (Shevchenko, Zolotukhina, 2005). This is the only record of this species near the Bug river (see fig. 6). In the catalogue of NMNHU-P, two more specimens from Pervomaisk are listed, No. 4862 (486) and 4863, with identical entries: "leucodon,

\footnotetext{
${ }^{2}$ In this article (Rusev et al., 2014) facts important to us are presented obtained due to observations on routes and reports of the locals: "On routes, as well as after interviewing the locals, the presence of a few more species was established: mole Talpa europaea, mole-rat Spalax (Nannospalax) leucodon" (p. 212). However, it remains unknown according to which characters these researchers identified the mole-rat on the route or whether there really are moles (locals often call mole-rats as "moles") in the depths of the steppe zone.

${ }^{3}$ Formally, the article by Filipchuk, Yangolenko (1986) is the most complete summary; however, there are no mentions of collected samples and records confirmed by morphological materials in it. Observations of mole-hills, information from SES or animal protection stations (where species identification is not considered at all) clearly prevail among these records. In addition, some of the points on the map are given under identical numbers, while a part of the numbers is missing from the map, and there is no explanation for several localities in the legend to the map.

${ }^{4}$ In the cited catalog "Zherebkovo" is given according to outdated information (the village is now referred to another district), and for unknown reasons this sample is recorded as S. microphthalmus (sic!).
} 
skeleton, Pervomaisk, Odesa reg., 1937, Reshetnyk". Both skulls were found and their identification as "leucodon" was confirmed. It is important that mole-rats in vicinities of Pervomaisk have been not recorded at least since 1958 (data by V. Kirichenko).

L4) Petrovirivka (Shyriaieve district, Odesa reg., valley of the Velyky Kuialnyk river). The specimen from this locality, according to label data and the record in the catalogue of NMNHU-P, has such initial data: "No. 2897 (2368/127), Spalax leucodon, skeleton, Petrovirivka, Tiraspol district, from Brauner's collection." This skull was investigated by us and its identification as leucodon was confirmed.

\section{B) Records in the south of Odesa region}

L5) Korsuntsi (Lyman district, eastern bank of the Kuialnyk estuary). Specimen in the collection of NMNHU-Z, skin and skull No. 16349, 25.05.2009, leg. P. Panchenko; skull with typical for N. leucodon characters, pink rhinarium (fig. 1; the photo was used in the Red Data Book of Ukraine).

L6) Vyzyrka (Lyman district, Odesa reg.). In 2016, a mole-rat with pink rhinarium was captured here, i.e. $N$. leucodon (P. Panchenko, pers. comm.); this finding was passed with a comment "the easternmost among mole-rat settlements that were discovered in the area between the Kuialnyk and Tylihul estuaries".

L7) Shompoly ${ }^{5}$ (Lyman district, Odesa reg.). In the catalogue of NMNHU-P, there is a series of records "Kominternivsky district, Odesa reg., Reshetnyk, 1937" (a part of specimens was collected in 1938, one specimen No. 3568 has exact date: 6.10.1937), all identified as "Spalax leucodon." In total there are 23 skulls (a part with skeletons) with No. 3568, 4843-4858, 4860-4861, 4864-4865, 4867-4868. In fact, 17 skulls and (or) mandibles were found in the collection, all of them are typical leucodon $\left(3568^{6}, 4843\right.$, 4845 7 , 4846-4851, 4853-4855, 4857, 4858, 4860, 4862, 4864, 4865, 4867, 4893, 4894, 4898, 4899).

L8) Liubopil (Lyman district, Odesa reg.). Records from about 2005, species identification was carried out by the description of body size and color of rhinarium (communication from a local mole-hunter).

L9) Pshonianove (former "Neu Peterburg", Lyman district, Odesa reg., eastern bank of the Kuialnyk estuary). Cottage areas, we received 1 specimen trapped 12.06.2016. According to the mole-hunter's communication, the species' expansion took place here: about 2000-2005 mole-rats occurred here only in the south, near the estuary (but they were common "on the opposite bank"), but about 2005 they appeared in Liubopil, then in Pshonianove, Butivka and later they spread further towards Odesa.

\section{Records of Spalax zemni}

Descriptions of 9 locations divided in two groups are given below. The first group includes records from the south of Mykolaiv region, namely from the right bank of the Southern Bug river (6 localities), while the second group includes records from the north of Mykolaiv region and from Kryvorizhia, i.e. the left bank of the Southern Bug river (5 localities). The first group is the most important because it regards the territory, which researchers attributed to geographical ranges of Nannospalax leucodon (fig. 6). In these limits there are also 6 locations in which mole-rats were found, but without data needed for diagnostics. Most of the known localities tend to the south of the region, where refugium settlements of the species occurred in the recent past.

In field conditions, it is also noteworthy that mole-hills of Spalax zemni are often much larger than those in the Odesian $N$. leucodon. It was repeatedly noted by the authors, in particular when comparing observations of mole-rat settlements in Shyrokolanivka (Spalax zemni) and adjacent locations (see below) with mole-rat settlements in the area located westwards of the Tylihul estuary, to the west from Kobleve (Nannospalax leucodon).

\footnotetext{
5 The labels indicate only the district "Kominternivsky." The name of the village was clarified based on the collector's work (Reshetnyk, 1941: 24). However, there are two villages with similar names, Stari and Novi Shompoly, situated next to each other.

${ }^{6}$ The mandible of this sample with the same number (No. 3568) was found in NMNHU-P.

${ }^{7}$ The sample's mandible was found in NMNHU-Z with the old (4845) and a new number (14925). These numbers (4845 and 14925) are in the catalogues of NMNHU-P and NMNHU-Z with the same original data ("leucodon, Reshetnyk, 1938, Kominter. dstr."), which are also written on the samples by Y. Reshetnyk's hand. However, on the skull 14925 in NMNHU-Z the old number was erased. Both samples are N. leucodon, but the second one has no lateral condylar canals (it was mentioned earlier as a character common for S. zemni: Korobchenko, Zagorodniuk, 2009). We believe that the error occurred in NMNHU-Z because of destruction of the original information.
} 


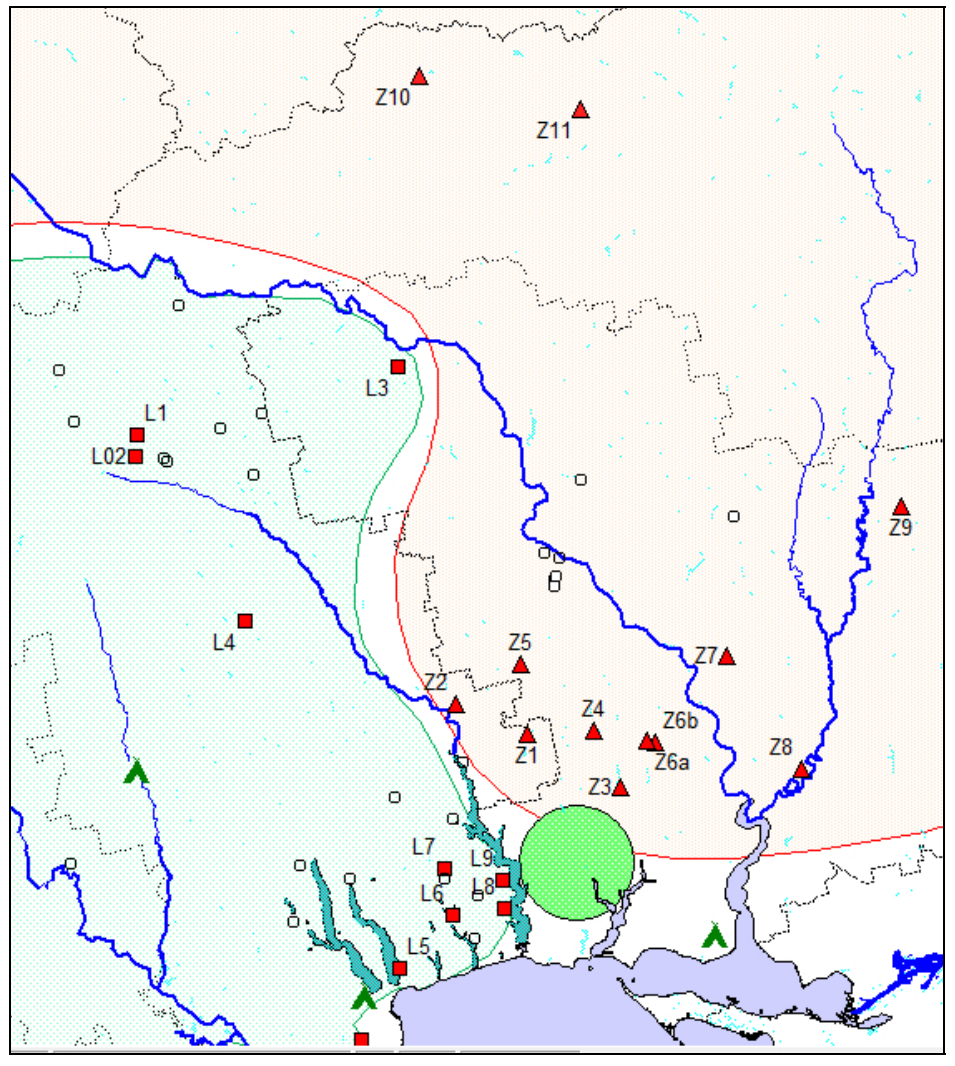

Fig. 6. Record localities of the two molerat species in the Northern Black Sea region.

\section{$\square$ Nannospalax leucodon,}

$\Delta$ Spalax zemni,

$\Lambda$ Spalax zemni subfoss.,

- Spalax indet.

Dark signs indicate localities with available morphological data, white circles indicate records without species identification. The big circle is the area between the Tylihul and Berezan estuaries, where colonies of S. zemni probably existed in the period of depression in 1940-2000, and from which the species expanded to north (localities Z2-Z6).

Рис. 6. Місця знахідок двох видів сліпаків у північному Причорномор'ї. Темні значки - місця, з яких є морфологічні дані, білі - знахідки без визначення виду. Коло - область між Тилігулом та Березанським лиманом, де найімовірніше зберігалися поселення S. zетпі у період депресії 1940-2000 pp. і звідки йшло заселення видом північніших ділянок (точки Z2-Z6).

\section{C) Records in the south of Mykolaiv region (right bank of the Southern Bug river)}

Z1) Osnova (Berezivka district, Odesa reg.). In the catalogue of NMNHU-P, there is a record No. 641 (313) "Spalax podolicus, skull, Osnova vil., Kherson reg., 28.07.1925, male, [leg.] Z. Holovianko (from Pidoplichka's collection)." This sample was not found in NMNHU-P. In the catalogue of NMNHU-Z, there is a record No. 2993 ("skin"): "Spalax arenarius, Osnova vil., Berezivka district, leg. Z. Holovianko, 28.07.1925" (Shevchenko, Zolotukhina, 2005), i.e. the same specimen, but only the label was found, with an additional No. 2369. We accept the species identification (zemni) after I. Pidoplichko.

Z2) Berezivka (Berezivka district, Odesa reg.), $3 \mathrm{~km} \mathrm{E,} \mathrm{25.05.2009.} \mathrm{Direct} \mathrm{observation;} \mathrm{the} \mathrm{color} \mathrm{of} \mathrm{rhi-}$ narium is dark-gray (E. Yablonovska-Grishchenko, pers. comm.).

Z3) Danylivka (Berezanka district, Mykolaiv reg.). Stable settlement, isolated for a long time; in 19982000 the mole-rat began to expand to the north, to Shyroky Lan, then to Ulianivka, and it was often registered in forest bands and fields. Then it spread further to the north, towards Voznesensk. Species identification is provisional and based on data about mole-rats expansion from here to Shyrokolanivka.

Z4a) Shyrokolanivka (Veselynove district, Mykolaiv reg.). In July 2005, in the Shyroky Lan military training ground, 6 samples from nests of Buteo rufinus were collected (leg. K. Redinov), which are deposited in the authors' collection (in NMNHU) (Korobchenko, Zagorodniuk, 2009) ${ }^{8}$. Another sample was collected nearly in 2012 and passed to the Mykolaiv Local History Museum (K. Redinov, pers. comm.). The species appeared here in the 2000s; in 2002-2005 it settled the whole military area, adjacent villages, and fields. The description of mole-rat population in this locality as "S. leucodon" (Rusev et al., 2015) was not based on morphological characters, but on the old views on mole-rat species ranges.

Z4b) Shyrokolanivka-2. A mole-rat was captured in the Shyroky Lan military area in autumn 2013, and the specimen was passed to the Mykolaiv Local History Museum (K. Redinov, pers. comm.). Species identification was carried out based on exterior features, including dark rhinarium (S. zemni).

\footnotetext{
${ }^{8}$ Data in the first communication were incomplete: "studied skulls of mole-rats from Veselynivsky district ... by the pattern of the occipital part of skull are identical to ... S. zemni" (Korobchenko, Zagorodniuk, 2009).
} 
Z5) Hryhorivka (Veselynove district, Mykolaiv reg.); trapped in 2013 at the crossroads of highways, its frozen carcass was deposited in the Mykolaiv Regional SES (sample was lost); identified by exterior characters (gray-black rhinarium, large body size; our data).

Z6a) Mykhailivka ("Ulianivka, Varvarivka district" = Mykhailivka vil., Mykolaiv district; the former "Varvarivsky district" in the 1960s was included into the Mykolaiv district). Detailed data lost; there is a record in the authors' registry "in our work collection there is a skull from Topachevsky's collection, 1963" (sample not found). Z6b) Mykhailivka ("Ulianivka", Mykolaiv district): it is a common species here since about 2005. Identification as zemni (without morphology) is based on the fact that this settlement is an unambiguous continuation of the population from Shyroky Lan (K. Redinov, our data), where the species settled in Ulianivka about 2002-2005 (our data).

\section{D) Records on the north of Mykolaiv region and in Kryvy Rih region (left bank of the Southern Bug)}

Z7) Nova Odesa ("Novoodesa district", Mykolaiv reg.). The find is attributed to the left bank of the Southern Bug. In the catalogue of NMNHU-P, there are 5 samples No. 4892, 4894, 4895, 4898, and 4899 with identical data: "Spalax polonicus, skeleton, male, Novoodesa district, Mykolaiv reg., 1938, Reshetnyk." Four of them were found in stocks of NMNHU-P, and the identification as S. zemni was confirmed (No. 4892, 4894, 4898, 4899). There was also found a skull without number, but with the following sign on skull: "female, Novoodesa district, Mykolaiv reg., 15.04.1938, Reshetnyk".

Z8) Kalynivka (Vitovka district, Mykolaiv reg.). Cottage areas near the Inhul river; trapped about 20132014, the sample (skin with the skull inside) is deposited in the Mykolaiv Local History Museum; its identification was carried out by K. Redinov based on external characters (including the color of rhinarium).

Z9) Novy Bug (Novy Bug district, Mykolaiv reg., valley of the Inhul river). In the catalogue of NMNHUP, there is a record "No. 4896, Spalax polonicus, skeleton, female, Novy Bug district, Odesa reg., 1938. Reshetnyk." We did not find this material in the stocks, but E. Reshetnyk's identification is authoritative; in addition, this record is located far from the distribution border of the species (see: fig. 6).

Z10) Novoarkhangelsk (Novoarkhangelsk district, Kirovohrad reg.). In the catalogue of NMNHU-P, there are records about 3 specimens No. 4893, 4900, 4959 (2 skeletons without skulls, and 1 skull): "Spalax polonicus, female, Novoarkhangelsk district, Odesa reg., 1938, Reshetnyk." The authors found the skulls No. 4893 and 4959 in NMNHU-P that allows confirming initial identification.

Z11) Khmeliove (Mala Vyska district, Kirovohrad reg.). Species from this locality was described earlier (Myhulin, 1938: p. 314 and fig. of the skull "from the collection of Zool. Mus. Acad. Sci.," 1927); the skull No. 1745 was found in NMNHU-Z; in the catalogue, there is a record "Spalax zemni, Odesa reg., Khmeliove district" (Shevchenko, Zolotukhina, 2005). In addition, 8 samples with entry "Spalax polonicus, Khmeliove district, Odesa reg., Reshetnyk, 1937" (6 skulls and 2 skeletons without skulls) are mentioned in the catalogue of NMNHU-P: No. 4888, 4889, 4901-4904, 4897, 4960. Two skulls were found in NMNHU-Z, No. 4902 and 4904: the first one has on its label the new No. 14927 with record "zemni," another with No. 4904 (current No. 14926) has the collector's record on the skull "polonicus."

\section{Conclusions}

The differences between two mole-rat species Nannospalax leucodon and Spalax zemni were evaluated by 6 revised exterior and cranial characters. Each of them is reliable in species identification, including the color of rhinarium, shape of rostrum, presence or absence of condylar canals, development of pharyngeal tubercles, flexion at the border of basioccipital and sphenoid bones, development of mandibular crest separating the intercrestal fossa. This complex of features allowed reidentifying a number of collection specimens that significantly changed the view on geographical ranges of the studied species.

The new data clearly showed that the boundary between the species ranges that has been considered so far along the Southern Bug river (e.g., in the Red Data Book of Ukraine (2009) and many other sources cited above) should be significantly shifted to the west: between the Southern Bug and Tylihul rivers occurs not Nannospalax leucodon, as it was believed by now, but another species Spalax zemni. This is confirmed by both old (1930s to 1950s) and modern samples (2010-2016). Therefore, it is not associated with long-term changes in species ranges, and the boundary between species as earlier as now run along the Tylihul river. 
At the same time, monitoring of mole-rat settlement dynamics demonstrates significant changes in the scope of inhabited areas. During at least 1958-2000, the territory of Mykolaiv region was free from mole-rats (data of the Mykolaiv Regional SES). Therefore, it is worthwhile to talk about a secondary occupation by mole-rats the most part of the Black Sea region from small refugia, which survived in the south, on the steppes near estuaries in Odesa and Mykolaiv regions.

The geographical boundary between the two species in the north of the region, obviously, runs along the Southern Bug river and through the Southern Bug-Dnister interriver area. Summarizing all data it can be assumed that Nannospalax leucodon is a recent entrant in the region.

\section{Acknowledgements}

The authors are sincerely thankful to colleagues who contributed to this study, in particular the curators of NMNHU collections O. Drobotun, L. Shevchenko, and O. Kovalchuk (Kyiv), as well as E. Yablonovska-Grishchenko, A. Lutsiuk (Odesa), K. Redinov (Ochakiv), and P. Panchenko (Odesa). Our thanks to Z. Barkaszi (NMNHU) for helping to prepare the manuscript.

\section{References • Література}

Filipchuk, N. S., Yangolenko, E. I. Recent distribution, population and ecological peculiarities of the lesser mole rat in the Ukraine // Vestnik zoologii. 1986. No. 1. P. 55-59. (in Ukr.) [Филипчук, Н. С., Янголенко, Е. И. Современное распространение, численность и особенности экологии белозубого слепыша на Украине // Вестник зоологии. 1986. № 1. C. 55-59.]

Korobchenko, M., Zagorodniuk, I. Taxonomy and levels of differentiation in mole-rats (Spalacidae) of the fauna of Ukraine and adjacent countries // Scientific Bulletin of the Uzhgorod Univ. Series Biology. 2009. Vol. 26. P. 13-26. (in Ukr.)

[Коробченко, М., Загороднюк, I. Таксономія та рівні диференціації сліпаків (Spalacidae) фауни України і суміжних країн // Науковий вісник Ужгородського ун-ту. Серія Біологія. 2009. Вип. 26. С. 13-26.]

Korobchenko, M. Variability and diagnostic value of cranial characters of Spalax microphthalmus: comparison with other Spalacidae species from Eastern Europe // Proceedings of the Theriological School. 2012 a. Vol. 11. P. 63-70. (in Ukr.)

[Коробченко, М. Мінливість та діагностична значимість краніальних ознак Spalax microphthalmus: порівняння 3 іншими видами Spalacidae зі Східної Європи // Праці Теріологічної Школи. 2012 а. Том 11. С. 63-70.]

Korobchenko, M. External features of mole-rats as criteria for species identification in field // State and Biodiversity of ecosystems of the Shatsk National Nature Park. Lviv : SPOLOM Press, 2012 b. P. 32-33. (in Ukr.)

[Коробченко, М. А. Екстер'єрні ознаки сліпаків як критерії видової ідентифікації в теренових умовах // Стан і біорізноманіття екосистем Шацького національного природного парку. Львів : СПОЛОМ, 2012 b. C. 32-33.]

Korobchenko, M. Burrowing rodents (Rodentia, Spalacidae et Ellobiusini) in zoological collections of Ukraine // Proceedings of the Zoological Museum. Kyiv, 2014. No. 45. P. 7078. (in Ukr.)

[Коробченко, М. Гризуни-землериї (Rodentia, Spalacidae et Ellobiusini) у зоологічних колекціях України // Збірник праць Зоологічного музею. Київ, 2014. № 45. С. 70-78.]

Korobchenko, M., Zagorodniuk, I. Mole-rat from Khortytsia in the light of morphological and geographical relations between Spalax zemni and S. microphthalmus // Proceedings of the Theriological School. 2016. Vol. 14. P. 85-94.

Myhulin, O. O. Mammals of the Ukrainian RSR (Materials to Fauna). Kyiv : Acad. Sci. of UkrSSR, 1938. 426 p. (in Ukr.) [Мигулін, О. О. Звірі УРСР (матеріали до фауни). Київ : Вид-во АН УРСР, 1938. 426 с.]
Pidoplichko, I. G. New data against the theory about hindrance of the Dnipro river // Quaternary Period. Kyiv, 1936. Is. 11. P. 75-83. (in Ukr.)

[Підоплічко, I. Г. Нові дані проти теорії про імпедитність р. Дніпра // Четвертинний період. Київ, 1936. Вип. 11. C. $75-83$.

Reshetnyk, E. Materials to study of systematics, geographic distribution and ecology of mole-rats (Spalacinae) in the Ukrainian RSR // Proceedings of the Zoological Museum. Kyiv, 1941. No. 24. P. 23-95. (In Ukr.)

[Решетник, $C$. Матеріали до вивчення систематики, географічного поширення та екології сліпаків (Spalacinae) УРСР // Збірник праць зоологічного музею. Київ, 1941. № 24. C. 23-95.]

Rusev, I., Zakusylo, V., Tverezovsky, M. et al. Small mammals of native steppe of the Shyrokolanivskyi military training ground // Visnyk of the Lviv University. Series Biology. 2014. Is. 65. P. 210-218. (in Ukr.)

[Русєв, I., Закусило, В., Тверезовський, М. та ін. Дрібні ссавці цілинного степу полігону «Широколанівський» // Вісник Львівського університету. Серія біологічна. 2014. Вип. 65. С. 210-218.]

Topachevsky, V. A. Mole-Rats (Spalacidae). Leningrad : Nauka Press, 1969. 248 p. (Fauna USSR; Vol. 3; Is. 3). (in Ukr.) [Топачевский, B. A. Слепышовые (Spalacidae). Ленинград : Наука, 1969. 248 с. (Фауна СССР; Том 3; Вып. 3).]

Tsemsh, I. O. To the question about significance of the Dnipro river as a zoogeographical border // Acta Musei Zoologici. Kyiv : Kyiv Univ. Press, 1941. Vol. 1. P. 307-311. (in Ukr.) [Цемш, I. О. До питання про значення Дніпра як зоогеографічної межі // Труди Зоологічного музею. Київ : Видво Київського ун-ту, 1941. Том 1 (1939). С. 307-311.]

Yangolenko, K. I. Bukovina mole-rat from the right-bank of the Prut river, its range and morphological features // Reports of the Academy of Sciences of Ukraine. 1966. No. 7. P. 965966. (in Ukr.)

[Янголенко, K. I. Грецький сліпак 3 правобережжя p. Прут, його ареал і морфологічні особливості // Доповіді АН Укр. РСР. 1966. № 7. С. 965-966.]

Zagorodniuk, I. V. Steppe fauna core of Eastern Europe: its structure and prospects of protection // Reports of the National Academy of Sciences of Ukraine. 1999. No. 5. P. 203210. (In Ukr.)

[Загороднюк, I. В. Степове фауністичне ядро Східної Європи: його структура та перспективи збереження // Доповіді НАН України. 1999. № 5. С. 203-210.] 